\title{
Identifikasi Nyamuk di Teluk Kecimbung, Kabupaten Sarolangun, Provinsi
} Jambi

\author{
Identification of Mosquitoes in Teluk Kecimbung, Sarolangun Regency, Jambi Province \\ Maas M Maloha ${ }^{1}$ \\ ${ }^{1}$ Dinas Kesehatan Provinsi Jambi \\ *Penulis Korespondensi. Maas M. MalohaEmail: maasmaloha@yahoo.com
}

\begin{abstract}
ABSTRAK
Latar Belakang: Angka kejadian malaria meningkat dari tahun ke tahun di Desa Teluk kecimbung. Peningkatan kejadian malaria dapat disebabkan peningkatan jumlah populasi nyamuk di daerah tersebut. Penelitian ini bertujuan mengidentifikasi nyamuk yang terdapat di Desa Teluk Kecimbung, Kabupaten Sarolangun, Provinsi Jambi.

Metode: Penelitian ini merupakan bagian dari survey lapangan tentang kepadatan nyamuk di daerah Desa Teluk Kecimbung. Penangkapan nyamuk melalui umpan relawan menggunakan aspirator dan cahaya lampu (light trap).

Hasil: Dari 489 nyamuk yang tertangkap saat pengambilan sampel. Nyamuk Armigeres merupakan komonitas nyamuk terbanyak yang tertangkap sebanyak 194 nyamuk (39.51\%), sedangkan jenis spesies nyamuk Anopheles yang tertangkap adalah Anopheles barbirostris sebanyak 28 nyamuk (5.70\%). Kepadatan hinggap nyamuk per jam (AHJ) tertinggi di dapatkan pada jam 20.00-21.00 WIB.
\end{abstract}

Kesimpulan: Nyamuk Anopheles barbirostris merupakan nyamuk anopheles yang terbanyak ditemukan di Desa Teluk Kecimbung, Kabupaten Sarolangun, Provinsi Jambi

Kata kunci: : nyamuk, Armigeres, Anopheles barbirostris, AHJ, Jambi

\section{ABSTRACT}

Background: Incidence of malaria has increased every year in Desa Teluk Kecimbung. The increase in malaria incidence can be caused by an increase in number of mosquito populations in that area. This study aims to identify mosquitoes found in the village of Teluk Kecimbung, Sarolangun Regency, Jambi Province.

Method: This research is part of a field survey of mosquito density in Teluk Kecimbung Village area. Catching mosquitoes through human volunteer using aspirators and light traps.

Results: Of 489 mosquitoes caught during sampling. The Armigeres mosquito is the most common mosquito caught by 194 mosquitoes (39.51\%), while the species of Anopheles mosquito caught is Anopheles barbirostris with 28 mosquitoes (5.70\%). The highest density of mosquitoes per hour (AHJ) is obtained at 20.00-21.00 WIB.

Conclusion: Anopheles barbirostris mosquito is the most common anopheles mosquito found in Teluk Kecimbung Village, Sarolangun Regency, Jambi Province.

Keywords: mosquitoes, Armigeres, Anopheles barbirostris, AHJ, Jambi 


\section{PENDAHULUAN}

Nyamuk merupakan vektor penyakit malaria, Demam Berdarah, Chikungunya, Jepanese Encephalitis dan filariasis yang merupakan masalah kesehatan masyarakat yang multikomplek. Penyakit tersebut menyerang segala golongan umur. Kejadian luar biasa penyakit tersebut sering terjadi terutama di daerah yang mengalami perubahan lingkungan, perpindahan penduduk dan lainlain. ${ }^{1}$

Malaria di Provinsi Jambi merupakan sepuluh penyakit terbesar, berdasarkan laporan dari puskesmas se Provinsi Jambi. Annual Malaria Incidence (AMI) di Kabupaten Sarolangun, Jambi selama tiga tahun berturut-turut meningkat yaitu $12,02 \%$ penduduk pada tahun 2014, 13.27\% penduduk tahun 2015, dan meningkat 14\%o penduduk tahun 2016. Data Puskesmas Limbur Tembesi, AMI selama tiga tahun berturut-turut juga terjadi fluktuasi yaitu $16,15 \%$ penduduk tahun 2014, menurun menjadi 15,95\% penduduk tahun 2015 dan meningkat $17,10 \%$ penduduk tahun 2016 . $^{2}$ Angka AMI di Desa Teluk Kecimbung selama tiga tahun berturut-turut juga mengalami peningkatan yaitu $15,18 \%$ penduduk tahun 2014 , naik menjadi $17,05 \%$ penduduk tahun 2015 dan 17,20\%o penduduk tahun $2016 .^{3}$

Penanggulangan malaria telah dilakukan tetapi jumlah kasus tetap tinggi, hal ini karena upaya penanggulangannya belum maksimal, di mana pelaksanaan pemberantasan malaria belum dilakukan secara baik dan tepat guna, penderita malaria dalam mengkonsumsi obat klorokuin dan primakuin tidak menurut aturan, tidak memperhatikan berbagai aspek bioekologi vektornya secara mendalam. ${ }^{4}$ Penelitian ini bertujuan untuk mengidentifikasi nyamuk yang terdapat di Desa Teluk Kecimbung, Kabupaten Sarolangun, Provinsi Jambi.

\section{METODE PENELITIAN}

Penelitian ini merupakan bagian dari survey lapangan tentang kepadatan nyamuk, dilakukan di Desa Teluk Kecimbung, Kabupaten Sarolangun, Provinsi Jambi. Pengambilan sampel dilakukan secara acak di Desa Teluk Kecimbung. Nyamuk diperoleh secara langsung melalui umpan relawan menggunakan aspirator (gambar 1) dan melalui perangkap cahaya menggunakan cahaya lampu (light trap).

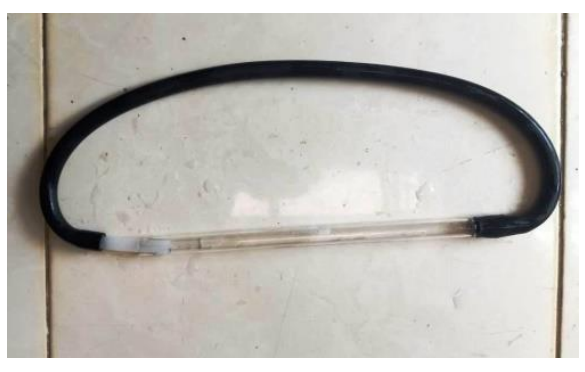

Gambar 1. Aspirator (sumber: dokumen pribadi)

Cara kerja penangkapan menggunakan aspirator adalah sebagian kaki dari relawan tersebut di buka, tunggu hingga ada nyamuk yang hinggap, tangkap nyamuk yang menghinggapi umpan dengan aspirator. Sampel nyamuk dimasukkan ke dalam bufferglass, kemudian diidentifikasi menggunakan mikroskop binokuler. Sedangkan penangkapan menggunakan cahaya dilakukan dengan meletakkan perangkap cahaya di dekat kandang di lingkungan permukinan penduduk. 
Angka Kepadatan hinggap nyamuk per jam (AHJ) dihitung per orang per satu jam, angka ini di dapatkan dari nyamuk yang

$$
\mathrm{AHJ}=\frac{\text { Jumlah tertangkap per spesies }}{\text { Jumlah jam penangkapan } \times \text { jumlah kolektor nyamuk }}
$$

\section{HASIL PENELITIAN}

Dari 491 nyamuk yang tertangkap saat pengambilan sampel di dapatkan sebaran jenis nyamuk seperti pada Tabel 1 .

Dari tabel 1. di dapatkan Nyamuk Armigeres merupakan komonitas nyamuk terbanyak yang tertangkap sebanyak 194 nyamuk (39.51\%) diikuti oleh culex sebanyak 149 nyamuk (30.35\%), Mansonia 96 nyamuk $(19.55 \%)$, dan sisaya adalah anopheles. Sedangkan jenis spesies nyamuk nopheles terbanyak yang tertangkap adalah Anopheles barbirostris sebanyak 28 nyamuk (5.70\%).

Angka hitung nyamuk per jam paling tinggi di dapatkan dari nyamuk Armigeres dengan jumlah 11.75, diikuti oleh culex 9.25, mansonia 5.75, dan Anopheles barbirostris 1.25 , serta AHJ tertinggi ditemukan pada jam 20.00-21.00 WIB (Tabel. 2).

Tabel 1. Jenis nyamuk tertangkap di Desa Teluk Kecimbung

\begin{tabular}{lcccc}
\hline \multirow{2}{*}{ Spesies } & \multicolumn{2}{c}{ Cara Penangkapan } & \multirow{2}{*}{ Total } & \multirow{2}{*}{$\%$} \\
\cline { 2 - 3 } & $\mathrm{UO}$ & $\mathrm{PC}$ & 28 & 5.70 \\
1. A.barbirostris & 20 & 8 & 18 & 3.67 \\
2. A.vagus & 15 & 3 & 12 & 2,44 \\
3.A.nigerrimus & 10 & 2 & 6 & 1.22 \\
4.A.aconitus & 5 & 1 & 5 & 1.02 \\
5.A. kochi & 4 & 1 & 2 & 0.41 \\
6.A.umbrosus & 2 & 0 & 149 & 30.35 \\
7.Culex & 141 & 8 & 194 & 39.51 \\
8.Armigeres & 180 & 14 & 96 & 19,55 \\
9. Mansonia & 89 & 7 & 491 & 100 \\
Total & 459 & 30 & PC = Perangkap cahaya &
\end{tabular}

Tabel 2. AHJ Nyamuk jam 20.00-24.00 di Desa Teluk kecimbung.

\begin{tabular}{lcccc}
\hline Spesies & $20.00-21.00$ & $21.00-22.00$ & $22.00-23.00$ & $23.00-24.00$ \\
\hline A. aconitus & 0,13 & 0,38 & 0,13 & 0,13 \\
A. barbirostris & 1,25 & 1 & 0,75 & 0,50 \\
A. kochi & 0,13 & 0,25 & 0,13 & 0,13 \\
A. nigerrimus & 0,38 & 0,50 & 0,38 & 0,13 \\
A. Umbrosus & 0,13 & 0,13 & 0 & 0 \\
A. vagus & 0,63 & 0,75 & 0,50 & 0,38 \\
Culex & 9,25 & 3,75 & 3,13 & 1,75 \\
Armigeres & 11,75 & 6,75 & 3,38 & 2,38 \\
Mansonia & 5,75 & 3,13 & 1,75 & 1,38 \\
\hline
\end{tabular}




\section{PEMBAHASAN}

Nyamuk Armigeres merupakan nyamuk terbanya pada periode penangkapan ini. Hal ini bisa dimungkinkan karenakan perbedaan tingkat kelembaban, tingkat curah hujan, dan lingkungan yang mempengaruhi kepadatan jumlah populasi nyamuk pada ekosistem tertentu. ${ }^{6}$

Jenis nyamuk lainnya yang tertangkap adalah anopheles. Anopheles yang tertangkap paling banyak adalah A. barbirostris. Hasil ini berbeda dengan penelitian yang dilakukan di Kecamatan Rajabasa, Lampung. Hasil penangkapan nyamuk di dapatkan jumlah kepadatan nyamuk tertinggi ditempati oleh Nyamuk Anopheles spp A. Sundaicus di ikuti oleh A Barbirostris dan A Vagus. ${ }^{6}$ Penyebaran nyamuk, jarak terbang, perilaku, ketahanan hidup dipengaruhi oleh beberapa faktor seperti cuaca, kecepatan arah angin, dan suhu. ${ }^{7}$ Nyamuk merupakan serangga berukuran kecil, halus, mempunyai bagian mulut untuk menusuk kulit dan menghisap darah. Indonesia telah ditemukan 457 spesies nyamuk tergolong dalam 18 genus, terdiri atas 80 sp Anopheles, 82 sp Culex, 125 sp Aedes dan 8 sp Mansonia. ${ }^{8}$

Nyamuk dinyatakan sebagai vektor apabila umur nyamuk panjang/ lama, sering kontak dengan manusia, kepadatan nyamuk tinggi, berfluktuasi dengan kasus yang ditimbulkannya, ditemukan parasit infektif dalam tubuh nyamuk atau pada kelenjer ludah nyamuk terdapat sprozoit untuk penyakit malaria dan pada probosis, palfi, antena terdapat microfilaria untuk penyakit filariasis. Indonesia telah dikomfirmasikan bahwa nyamuk kususnya Anopheles sebagai vektor yaitu 21 spesies terdiri dari A. barbirostris, A. aconitus, A. nigerrimus, A. umbrosus, A. sundaicus, A. maculatus, A. sinensis, A. letifer, A. balabacensis, A. punctulatus, A. farauti, A. bancrofti, A. karwari, A. koliensis, A. subpictus, A. flavirostris, A. minimus, A. censis, A. peditaeniatus, A. vagus dan A. longirostris. ${ }^{9}$
Dari hasil pengamatan. Kepadatan nyamuk tertinggi terjadi pada jam 20.0021.00 WIB. Nyamuk khusunya Anopheles mencari darah pada sore hari dan malam hari masuk rumah untuk memperoleh darah, beristirahat di dinding rumah lalu siang hari beristirahat di pinggiran kolam dan sangat banyak ditemukan di kandang ternak. Pertumbuhan dan perkembangan populasi nyamuk pada habitatnya sangat dipengaruhui oleh ketersediaan makanan dan darah serta lingkungannya seperti suhu udara, kelembaban udara, cuaca, curah hujan, tempat berkembang biak, tempat pemenuhan kebutuhan fisiologis dan tempat istirahat. ${ }^{10}$

Angka hinggap per Jam nyamuk Anopheles di dalam rumah sepanjang malam menggambarkan spesies tersebut masuk kedalam rumah untuk berkontak dengan manusia, hal ini penting diketahui memprediksi terjadinya transmisi penyakit akibat vector nyamuk di dalam masyarakat setiap jamnya.

Angka-angka tersebut diatas menunjukkan perbedaan waktu puncak hinggap perspesies setiap jamnya, disebabkan oleh faktor geografi seperti ketinggian dari permukaan laut, curah hujan sepanjang hari, bulan dan tahun, selain itu jenis habitat yang ada, ketersediaan kandungan zat makanan, maupun kompetisi antar dan inter spesies yang ada. Makin stabil suatu daerah makin komplek kehidupan fauna dan kepadatan nyamuknya.

\section{UCAPAN TERIMA KASIH}

Ucapan terima kasih kepada Dr. Suwito, SKM, M.Si selaku Kasubdit Vektor dan Kepala Bidang P2P Dr.Hj. Eva Susanti, SKP, M.Kes yang telah memberikan waktu kepada penulis untuk meneliti dan menyelesaikan tugas ini dengan baik. Serta tak lupa penulis ucapkan terima kasih banyak kepada Kepala Desa, perangkat Desa dan Warga dari Desa Teluk Kecimbung Kabupaten Sarolangun yang telah banyak membantu penulis dalam proses penelitian dan pengambilan data dan sampel serta pihak lain yang telah membantu dan berkontribusi dalam penyelesaian penulisan dan penelitian ini. 


\section{DAFTAR PUSTAKA}

1 Departemen Kesehatan RI. Pedoman ekologi dan aspek perilaku vektor. Jakarta: Direktorat Pemberantasan Penyakit Bersumber Binatang Direktorat Jenderal PPM \& PL. 2001.

2 Dinas Kesehatan Sarolangun. Puskesmas limbur tembesi angka annual malaria incidence (ami). Jambi: Dinas Kesehatan Kabupaten Sarolangun. 2016

3 Bides Desa Teluk Kecimbung. Angka annual malaria incidence (ami) desa teluk kecimbung. Jambi: Dinas Kesehatan Kabupaten Sarolangun. 2016

4 Barodji, Damar TB, Hasan B, Sudini, Sumardi. Binomik vektor dan situasi malaria di kecamatan kokap, kabupaten kulonprogo, yogyakarta. Jurnal ekologi kesehatan. 2003;2(2):209-216

5 Rao TR. The anophelines of india. India: Cornell University India: Malaria Research Centre, Indian Council of Medical Research. 1984.

6 Suwito, Hadi UK, Sigit SH, Sukowati S. Distribusi spasial dan bioekologi Anopheles spp. di Lampung Selatan dan Pesawaran, Provinsi Lampung. Jurnal Ekologi Kesehatan. 2010;9(3):1290-1302.

7 Boewono DT. Referensi nyamuk di jawa tengah dalam koleksi nyamuk di indonesia. Stasiun Penelitian Vektor Penyakit. DepKes RI. 1999.

8. O'Connor CT, Sopa T. A checklist of the mosquitoes of Indonesia. A Special Publication of the US-Naval Medical Research Unit No. 2 (NAMRU-2). Jakarta, Indonesia. 1981.

9. Sigit HS. editors. Parasitology and parasitic deseases in indonesia (a country raport). The $1^{\text {st }}$ Congress of Federation of Asian Parasitologists in Chiba, Japan. 2000. Chiba: Japan.

10. Rozendal JA. Vektor control: methods for use by indiduals and communitas. Geneva: WHO. 1997. 